\title{
THE SOUTH-EASTERN DISTRIBUTION LIMIT OF Apis mellifera, A MORPHOMETRIC STUDY OF THE HONEY BEES (Apis mellifera L.) OF SISTAN-BELUTSCHISTAN
}

\author{
Apis mellifera'nın Güney-Doğu Yayılış Sınırları, Sistan-Belutschistan Balarılarında \\ (Apis mellifera L.) Morfometrik Çalışma \\ (Genişletilmiş Türkçe Özet Makalenin Sonunda Verilmiştir)
}

Mohammad Reza POURELMI, Stefan FUCHS

\begin{abstract}
Department of Animal Science, Islamic Azad University (IAU), Chalous Branch, IRAN
Institut für Bienenkunde, Faculty of Life Sciences, Goethe-University Frankfurt am Main, GERMANY

Geliş Tarihi: 25.02.2017

Kabul Tarih: 15.04.2017
\end{abstract}

\begin{abstract}
The western honeybee, Apis mellifera, covers an immense range of natural distribution. In contrast to the limits in the North, West and South defined by the sea, the continental limits in the East are far less clear. Here we present detailed morphometric data on the Bees of Sistan-Belutschistan in the far South-Eastern End of the A. mellifera distribution. These are of particular interest because they inhabit a comparatively narrow desert climate land strip separating the distribution range from the Eastern honey bee, Apis cerana. Samples from the area differed quite substantially from the nextneighboured Iran bee population, particularly by small body size, short hair, coloration patterns, and comparatively broad wings, but were clearly allocated to $A$. m. meda rather than to other representative $A$. mellifera subspecies. The study expands the South-Eastern range of $A$. m. meda by a particularly heat-adapted subpopulation, considerably narrowing the geographic gap to $A$. cerana in Pakistan.
\end{abstract}

Keywords: Apis mellifera meda, distribution range, morphometry

Öz

Batı bal arısı Apis mellifera çok geniş doğal bir yayılışa sahiptir. Batı ve Güney'deki sınır denizle tanımlanırken Doğu'daki kıtasal sınır Kuzey sınırına göre çok daha belirsizdir. Burada Apis mellifera'nın Güneydoğu sınırının son kısmında Sistan-Belutschistan arıları hakkında detaylı morfometrik verileri sunuyoruz. Bu bölge özel ilgi alanıdır çünkü bu arılar oldukça dar bir çöl iklim bölgesinde Doğu arısı Apis cerena yayılış bölgesini ayıran bir çizgide bulunmaktadır. Bölgeden alınan numuneler hemen aynındaki İran arı populasyonundan oldukça farklı olup özellikle küçük vücut büyüklüğü, kısa kıllar, renk durumları, karşılaştırmalı geniş kanatları ile başka bir Apis mellifera alt türünden çok net bir şekilde $A$. $m$. meda'ya dahil olmaktadır. Bu çalışma $A$. m. meda'nın güneydoğu bölgesine uzanan sıcaklığa adapte olmuş alt populasyonu olup A.cerana ile aradaki coğrafik boşluğu ciddi şekilde daraltmaktadır.

Anahtar Kelimeler: Apis mellifera meda, yayılış alanı, morfometri 


\section{ARAŞTIRMA MAKALESI /RESEARCH ARTICLE}

\section{INTRODUCTION}

In this study we reinvestigate the south-eastern distribution of Apis mellifera, in an area of specific interest. The South-Eastmost region of Iran, SistanBelutschistan, forms a land strip of about $1100 \mathrm{~km}$, which stretches from Zabol bordering Afghanistan in the North, along the border of Pakistan to Chabahar in the South, at the Golf of Oman (Fig. 1). It covers an area of about $181578 \mathrm{~km}^{2}$ inhabited by about $2.4 \mathrm{~m}$ people. Little is known about honey bees and beekeeping in this region dividing the distribution ranges of $A$. mellifera and $A$. cerana without any apparent overlap. According to Ruttner et al (1985), the most eastern $A$. mellifera were found close to Dalfarh $\left(28^{\circ} 58 \mathrm{~N} 57^{\circ} 38 \mathrm{E}\right)$ in the district of Kerman, located west of SistanBelutschistan. They reported that there were no $A$. mellifera bees in Sistan-Belutschistan due to its extremely dry desert climate, but reported the presence of the dwarf honey bee, $A$. florea. More to the East, from Pakistan and Afghanistan onwards, the Eastern honey bee, Apis cerana, is found.

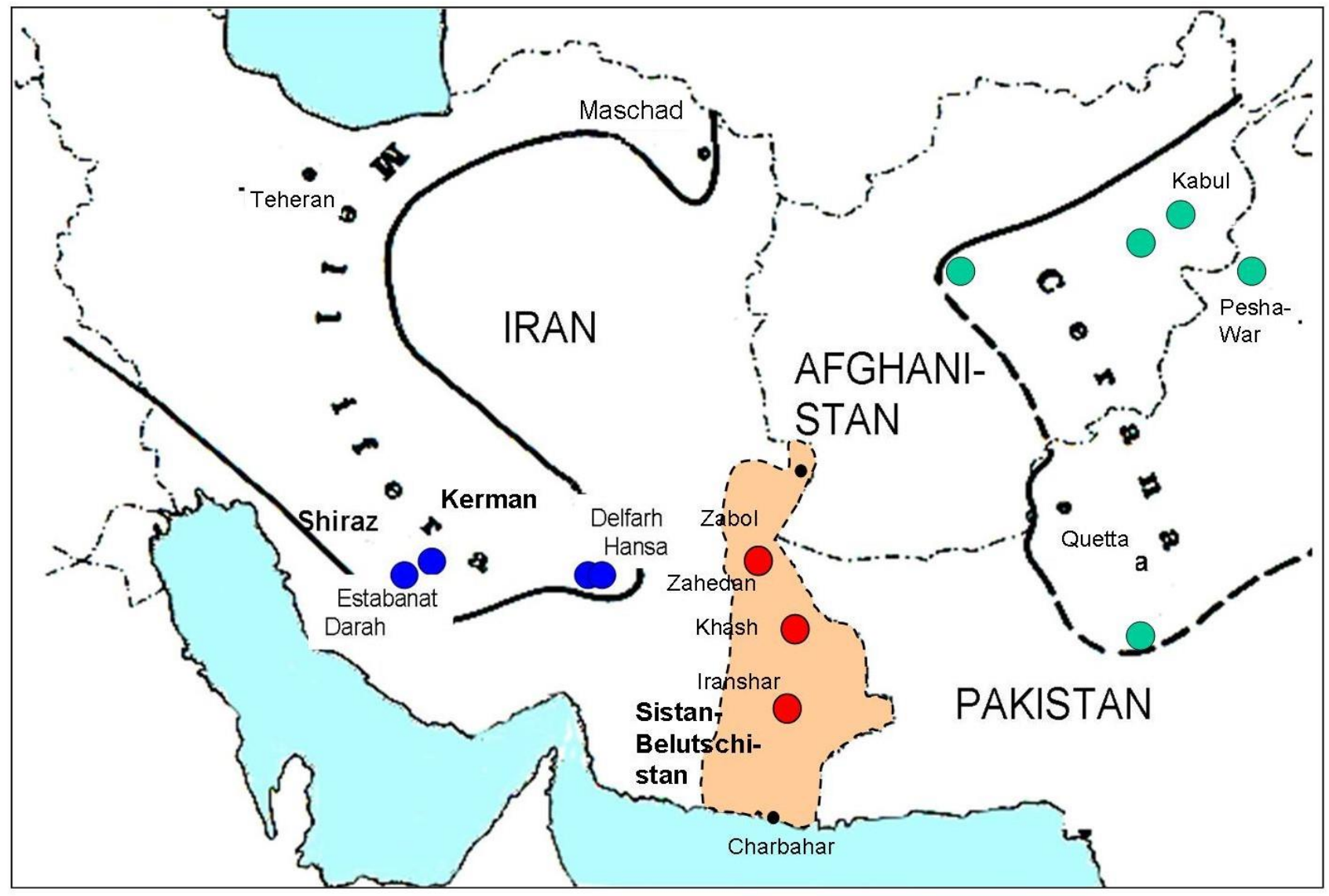

Fig. 1 The south-eastern boundaries of the $A$. mellifera distribution area, as well as the west-eastern boundaries of $A$. cerana, modified from Ruttner et al. (1985). The blue symbols give the hitherto eastmost sampling locations of $A$. mellifera, green symbols the westmost of $A$. cerana. Red symbols show the sampling locations in this study. No $A$. mellifera bees were found at Charbahar.

In this study, a reinvestigation of that Eastern limit of $A$. mellifera distribution range was undertaken. In a sampling excursion in 2005 , we found that quite some beekeeping takes place in the area.
According to local estimates this comprised of 1299 beekeepers in the year 1998, which had decreased to about 200 in 2005 due to long-lasting periods of extreme dearth $(>22 \mathrm{~mm}$ rainfall/year). Traditional 


\section{ARAŞTIRMA MAKALESI / RESEARCH ARTICLE}

beekeeping had been performed using common clay pot hives, but at that time the about 3.000 colonies were kept modern Langstroth hives. A wide variety of plants are visited by the bees for honey and pollen. Bees are prone to swarming, and are fairly defensive. Common natural enemies of the bees were Beewolves (Philantus spec.), bee eaters, and ants. In 2015, Rahini undertook a mtDNA study on $A$. meda including 3 sample locations of bees in Sistan-Belutschistan. In the current study we present a detailed morphometric study of these bees, and explore their morphological relation to other bee subspecies.

\section{MATERIALS AND METHOD}

One of us (Pour Elmi) collected Apis mellifera honey bees from 7 colonies in the region. In 2005, four locations were visited. From South to North: no A. mellifera bees were found at Chabahar (Bandar Beheshti, $\left(25^{\circ} 17^{\prime} \mathrm{N} 60^{\circ} 36^{\prime} \mathrm{E}\right.$, altitude 0 to $\left.100 \mathrm{~m}\right), 3$ samples were taken from Iranshahr $\left(27^{\circ} 10^{\prime} \mathrm{N}\right.$, $60^{\circ} 38^{\prime} \mathrm{E}$, altitude $\left.660 \mathrm{~m}\right) .1$ from Khash $\left(28^{\circ} 13^{\prime} \mathrm{N}\right.$, $61^{\circ} 11^{\prime} \mathrm{E}$, altitude $14900 \mathrm{~m}$, and another 3 from Zahedan $\left(29^{\circ} 30^{\prime} \mathrm{N}, 60^{\circ} 50^{\prime} \mathrm{E}\right.$, altitude $\left.1384 \mathrm{~m}\right)$. Mean annual temperatures were high in all locations $\left(20-28^{\circ} \mathrm{C}\right)$ with average July temperatures between $\left.27-34^{\circ} \mathrm{C}\right)$. Average rainfall is generally low $(<110 \mathrm{~mm} /$ year), humidity is high at the coast $(85 \%$, Chabahar), but low within the inland (25 to 50\%). A.florea was noted in all locations except Zahedan. Sampling beeyards were selected where beekeepers were not engaged in breeding, and did not move their colonies. Each sampled colony was at least $30 \mathrm{~km}$ distant from any other to avoid close relatedness. At least ten worker bees were taken from each sampled colony, and were stored in 95\% Ethanol for later analysis.

10 worker bees per colony were analyzed according to the methods described in Ruttner (1988), using 37 morphometric characters (16 sizes, 7 colors, 3 pilosity, and 11 wing angles). Measurements of size and wing venation were performed using a stereo microscope and a computer-aided measuring system based on a video system and measuring program (Meixner 1994). For measurements of pilosity and color scaling a stereo microscope was used. To determine the morphometric position within the species, data from 67 samples of $A$. m. meda and 128 samples of other adjacent subspecies were obtained from the Oberursel data bank. Results were analysed by discriminant analysis and UPGMA Cluster Analysis using SPSS 23 (2015).

\section{RESULTS}

A selection of morphometric data are listed in Table 1 , together with Oberursel data bank data for the most relevant subspecies and $A$. m. meda subgroups. Due to low numbers of colonies sampled in Sistan-Belutschistan, sampling locations were not differentiated. The honey bees of SistanBelutschistan were small in relation to most of the other bee groups, and differed highly significantly in almost all length measurements from the data bank measurement of $A$. m. mellifera, A. m. carnica, $A$. $m$. caucasica and $A$. $m$. anatoliaca (univariate comparisons with LSD post-hoc comparisons), but were similar in size to $A$. m. syriaca. However, they were markedly bigger than $A$. $m$. jemenitica, where all size measurements were significantly smaller. They were also slightly smaller in relation to other meda groups (Iran central, Iran North-East (NE), Iran South-East (SE) Iran Mazandaran, and Irak, but only about half of the measurements were statistically different. In particular, they were very similar to the other meda groups in the waxmirror dimensions and the metatarsal length and width. An outstanding character was wing dimensions. While wing length ranged similar as other length measurements, wing width measures were significantly higher in comparison to all other groups except $A$. m. carnica and Iran NE. Consequently, forewing index (length/width) was significantly higher in all comparisons. SistanBelutschistan bees did not show an exceptional position in relation to the other groups in slenderness (lengt/width of sternum 6) nor in the relation of body size to leg length.

Hairlength was significantly shorter than in all the other bee groups, with the exception of A. m. jemenitica where it was significantly shorter. Tomentum width differed significantly only from the higher value of $A$. $m$. caucasica, while the dark stripe differed significantly only from the higher values in $A$. m. mellifera and $A$. $m$. Iran NE.

Sistan-Belutschistan bees were fairly light colored. In particular, pigmentation of tergite 4 was significantly lighter than in any of the other groups. Tergite 2 and 3 pigmentations were considerably and significantly lighter in comparison to $A . m$. mellifera, A. m. carnica, A. m. caucasica and A. m. 


\section{ARAŞTIRMA MAKALESII /RESEARCH ARTICLE}

anatoliaca. While tergite 2 pigmentation did not differ throughout the other groups, tergite 3 pigmentation was significantly darker in comparison to $A$. m. syriaca, A. m. jemenitica and the $A$. $m$. meda groups from Central Iran and Irak. Pigmentation of the scutellum was generally lighter than in all other groups, the differences were significant except for scutellum 1 in comparison to A. $m$. jemenitica, Iran SE and Irak, and for scutellum 2 in comparison to $A$. m. caucasica $A$. m. syriaca and $A$. $m$. jemenitica. In contrast, pigmentation of labrum 1 was significantly darker than all other groups (except $A$. m. jemenitica, Iran SE and Irak where the difference was not significant). Pigmentation of labrum 2 was darker than in the $A$. m. meda groups and $A$. $m$. jemenitica, which difference was significant for Iran SE and Irak, but was lighter in comparison to the other groups which was significant only for A.m.caucasica.

Table 1. Morphometric characteristis of Sistan-Belutschistan honey bees (A. mellifera), and data on other subspecies or $A$. meda subgroups obtained from the Oberursel Data Bank. Significance of difference to Sistan-Belutschistan: * $P>0.05,{ }^{* *} P<0.005{ }^{* * *} P<0.0005$

\begin{tabular}{|c|c|c|c|c|c|c|c|c|}
\hline & & & & & \multicolumn{4}{|l|}{ A. m. meda } \\
\hline & $\begin{array}{l}\text { A. } m \text {. } \\
\text { caucasica }\end{array}$ & $\begin{array}{l}\text { A. } m \text {. } \\
\text { anatoliaca }\end{array}$ & $\begin{array}{l}\text { A. } m . \\
\text { syriaca }\end{array}$ & $\begin{array}{l}\text { A. } m \text {. } \\
\text { jemenitica }\end{array}$ & Iran central & Iran SE & Irak & $\begin{array}{l}\text { Sistan- } \\
\text { Belutschistan }\end{array}$ \\
\hline $\begin{array}{l}\text { Body size } \\
(\text { LT3+LT4). (mm) }\end{array}$ & $\begin{array}{l}4.54 \\
0.075^{* * *}\end{array}$ & $\begin{array}{l}4.48 \\
0.059 * * *\end{array}$ & $\begin{array}{l}4.19 \\
0.132 \text { * }\end{array}$ & $\begin{array}{l}3.88 \\
0.115^{* * *}\end{array}$ & $\begin{array}{l}4.35 \\
0.089 \mathrm{~ns}\end{array}$ & $\begin{array}{l}4.48 \\
0.111^{* * *}\end{array}$ & $\begin{array}{l}4.29 \\
0.113 n s\end{array}$ & $\begin{array}{l}4.28 \\
0.057\end{array}$ \\
\hline $\begin{array}{l}\text { Complete leg } \\
\text { fem+tib+mtar. }(\mathrm{mm})\end{array}$ & $\begin{array}{l}8.27 \\
0.144 \text { *** }\end{array}$ & $\begin{array}{l}8.14 \\
0.104 \text { *** }\end{array}$ & $\begin{array}{l}7.87 \\
0.144 \text { * }\end{array}$ & $\begin{array}{l}7.02 \\
0.201 \mathrm{~ns}\end{array}$ & $\begin{array}{l}7.81 \\
0.163 \mathrm{~ns}\end{array}$ & $\begin{array}{l}7.92 \\
0.153 \text { * }\end{array}$ & $\begin{array}{l}7.76 \\
0.127 \mathrm{~ns}\end{array}$ & $\begin{array}{l}7.75 \\
0.138\end{array}$ \\
\hline $\begin{array}{l}\text { Forewing index } \\
\text { wfw/lfw }\end{array}$ & $\begin{array}{l}0.34 \\
0.003 \text { *** }\end{array}$ & $\begin{array}{l}0.34 \\
0.004 \text { *** }\end{array}$ & $\begin{array}{l}0.33 \\
0.003^{* * *}\end{array}$ & $\begin{array}{l}0.34 \\
.004^{* \star *}\end{array}$ & $\begin{array}{l}0.34 \\
0.004 \text { *** }\end{array}$ & $\begin{array}{l}0.34 \\
0.005^{* * *}\end{array}$ & $\begin{array}{l}0.34 \\
0.005^{* * *}\end{array}$ & $\begin{array}{l}0.35 \\
0.005\end{array}$ \\
\hline Hair lenght. (mm) & $\begin{array}{l}0.34 \\
0.034 \text { *** }\end{array}$ & $\begin{array}{l}0.29 \\
0.025 \text { ** }\end{array}$ & $\begin{array}{l}0.22 \\
0.037 \text { * }\end{array}$ & $\begin{array}{l}0.18 \\
0.019 * * *\end{array}$ & $\begin{array}{l}0.28 \\
0.033 \text { ** }\end{array}$ & $\begin{array}{l}0.28 \\
0.016^{\star \star}\end{array}$ & $\begin{array}{l}0.28 \\
0.018 \text { * }\end{array}$ & $\begin{array}{l}0.25 \\
0.029\end{array}$ \\
\hline Pigment tergit 4 & $\begin{array}{l}1.53 \\
0.86 * * *\end{array}$ & $\begin{array}{l}2.81 \\
0.70 * * *\end{array}$ & $\begin{array}{l}3.83 \\
0.25 * * *\end{array}$ & $\begin{array}{l}4.38 \\
0.80 * * *\end{array}$ & $\begin{array}{l}4.33 \\
0.68 \text { ** }\end{array}$ & $\begin{array}{l}4.66 \\
0.89 * * *\end{array}$ & $\begin{array}{l}5.82 \\
0.27^{* * *}\end{array}$ & $\begin{array}{l}6.41 \\
0.49\end{array}$ \\
\hline Pigment tergit 2 & $\begin{array}{l}3.60 \\
0.86^{* * *}\end{array}$ & $\begin{array}{l}4.77 \\
0.89 * * *\end{array}$ & $\begin{array}{l}8.56 \\
0.43 \mathrm{~ns}\end{array}$ & $\begin{array}{l}8.06 \\
0.85 \mathrm{~ns}\end{array}$ & $\begin{array}{l}8.56 \\
0.43 \mathrm{~ns}\end{array}$ & $\begin{array}{l}8.34 \\
0.55 \mathrm{~ns}\end{array}$ & $\begin{array}{l}8.92 \\
0.25 \mathrm{~ns}\end{array}$ & $\begin{array}{l}8.07 \\
0.59\end{array}$ \\
\hline Pigment scutellum 1 & $\begin{array}{l}1.57 \\
0.82 \text { *** }\end{array}$ & $\begin{array}{l}3.91 \\
1.42 \text { *** }\end{array}$ & $\begin{array}{l}5.91 \\
0.95 \text { * }\end{array}$ & $\begin{array}{l}6.30 \\
0.69 \mathrm{~ns}\end{array}$ & $\begin{array}{l}5.93 \\
0.99 *\end{array}$ & $\begin{array}{l}6.11 \\
0.44\end{array}$ & $\begin{array}{l}6.69 \\
0.53 *\end{array}$ & $\begin{array}{l}6.78 \\
0.56\end{array}$ \\
\hline Angle A4 (degree) & $\begin{array}{l}34.6 \\
1.54 \text { *** }\end{array}$ & $\begin{array}{l}33.0 \\
1.12 \text { ** }\end{array}$ & $\begin{array}{l}32.6 \\
1.29\end{array}$ *** & $\begin{array}{l}34.3 \\
1.21^{\text {*** }}\end{array}$ & $\begin{array}{l}30.6 \\
1.37^{\text {*** }}\end{array}$ & $\begin{array}{l}29.9 \\
0.85\end{array}$ * & $\begin{array}{l}30.20 \\
0.98\end{array}$ & $\begin{array}{l}28.4 \\
* 1.07\end{array}$ \\
\hline Angle K19 (degree) & $\begin{array}{l}75.0 \\
2.32 \text { *** }\end{array}$ & $\begin{array}{l}77.8 \\
2.00 \text { *** }\end{array}$ & $\begin{array}{l}79.9 \\
2.16^{\star \star}\end{array}$ & $\begin{array}{l}81.1 \\
1.53 \mathrm{~ns}\end{array}$ & $\begin{array}{l}78.7 \\
1.58^{\star \star *}\end{array}$ & $\begin{array}{l}80.0 \\
1.46 \text { ns }\end{array}$ & $\begin{array}{l}80.5 \\
1.65 \text { ns }\end{array}$ & $\begin{array}{l}82.4 \\
1.89\end{array}$ \\
\hline
\end{tabular}

In the 11 wing venation angles, SistanBelutschistan bees differed significantly from the other groups in 72 of 121 possible comparisons. They differed in most angles (9 out of 11) from $A$. m. mellifera, A. m. carnica, $A$. $m$. anatoliaca and $A$. $m$. anatoliaca, in somewhat more than half from $A$. $m$. syriaca and $A$. $m$. jemenitica, and in somewhat less than half from the $A$. $m$. meda groups (about 5 out of 11). Some angles took extreme positions. Angle A4 and Angle O26 were significantly smaller than in all other groups (except A4 in comparison to A. m. carnica and Iran NE, and $\mathrm{O} 26$ in comparison to Iran NE Iran Mazandaran, and Irak, where differences were not significant. Angel b4, G18 and K19 were significantly larger than in all other groups (except b4 in comparison to A. m. carnica and G18 as well as $\mathrm{K} 19$ in comparison to $A$. $m$. jemenitica where differences were not significant). Cubital vein 1 was significantly longer than in $A$. $m$. jemenitica, but shorter than in $A$. $m$. carnica, IranNE and IranSE, vein 2 was also significantly larger than in A. $m$. jemenitica but smaller than $A$. m. mellifera, $A$. $m$. caucasica and $A$. $m$. anatoliaca. Cubital index was significantly lower in comparison to $A$. m. 


\section{ARAŞTIRMA MAKALESI / RESEARCH ARTICLE}

carnica and IranSE, but higher in comparison to $A$. m. mellifera, A. m. caucasica, A. m. anatoliaca and A. $m$. jemenitica. Differences were not significant in the other comparisons.

In discriminant analysis, when entered as an own group the bees from Belutschistan were positioned adjacent to the $A$. m. meda groups (Fig. 2 a), with some affinity to $A$. $m$. syriaca or $A$. $m$. anatoliaca. They were distinct enough from all other groups that each sample was reallocated to their own group with very high probability $(P>0.9995)$. When entered as unclassified samples, all were assigned with very high post-hoc probability to $A$. m. meda
( $P>0.9995$ in all but the sample from Khash, where $P$ was 0.996).

A separate discriminant analysis of the SistanBelutschistan samples together with the $A$. $m$. meda groups alone again emphasized the comparatively high distance of these bees from the other groups, predominantly because of their smaller size reflected on discriminant function 1 (Fig 1b). As ungrouped samples, all SistanBelutschistan samples were allocated to the Iran SE group with very high probability $(P>0.9995)$, except one sample from Iranshar which was allocated to the Irak meda group with lower probability of $\mathrm{P}=0.965)$.

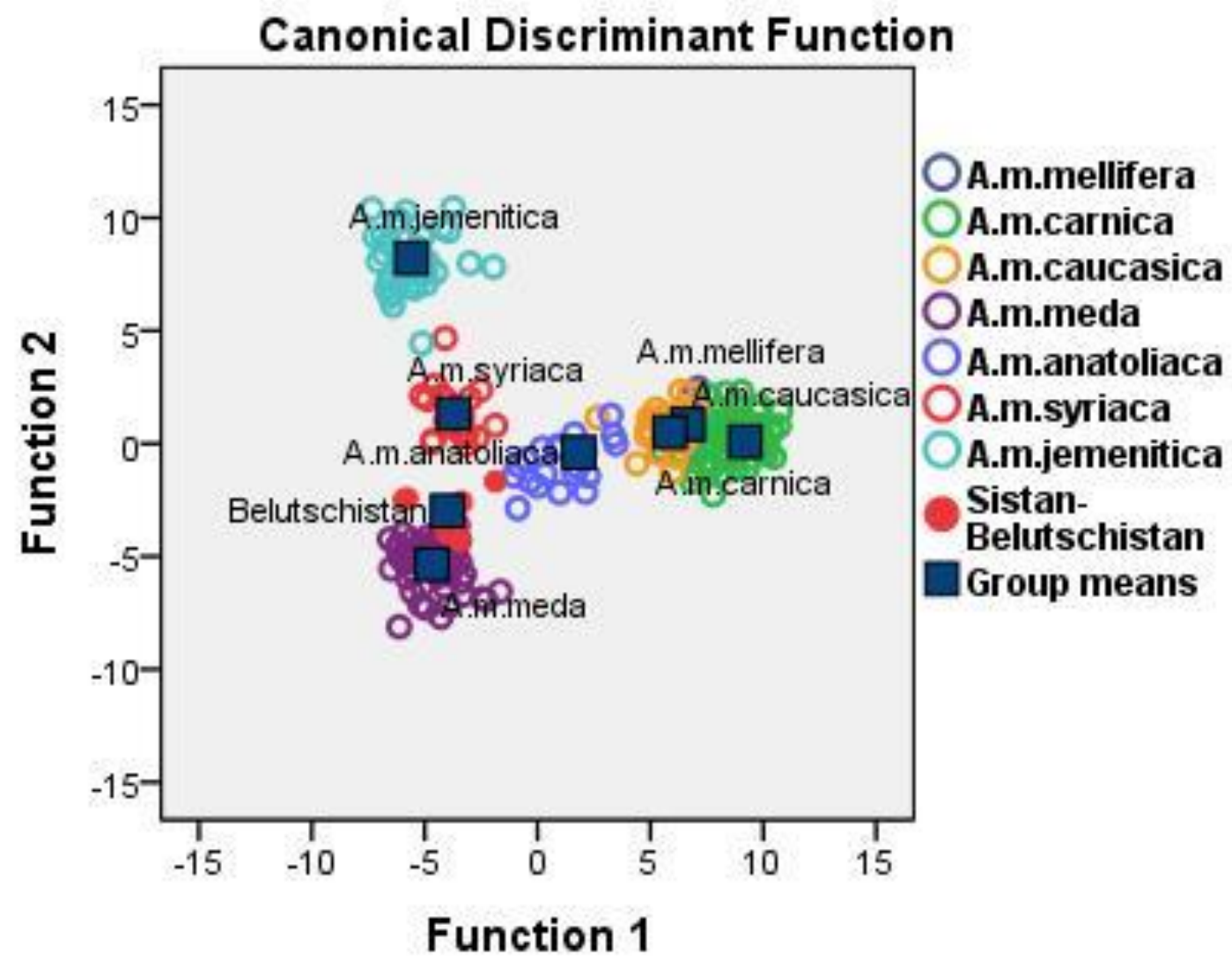

Fig.2a Discriminant analysis function plots. a for the grouped Sistan-Belutschistan samples together with all other subspecies, b for the ungrouped Sistan-Belutschistan samples together with the A. m. meda subgroups. 


\section{Canonical Discriminant Function}

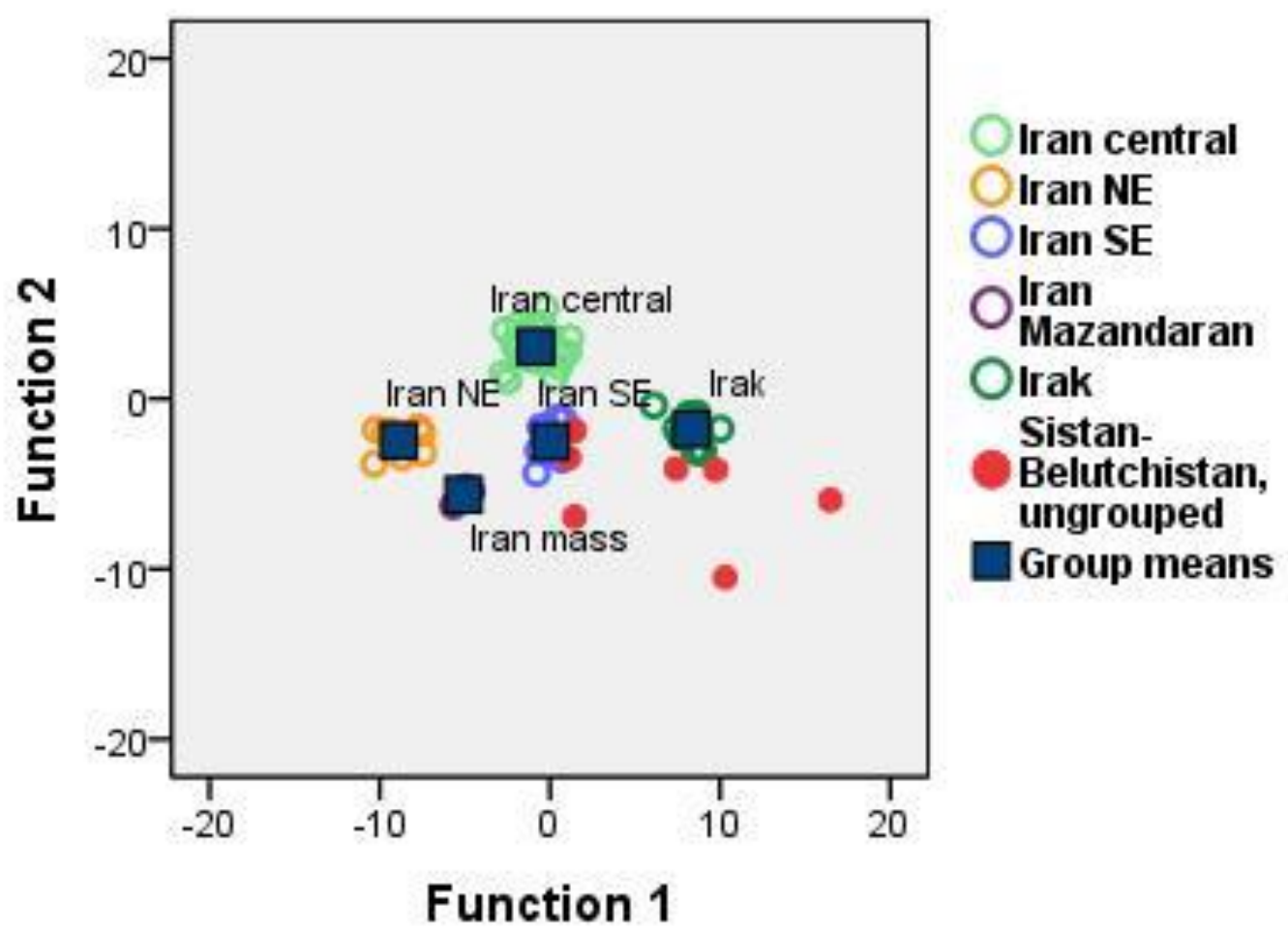

Fig. 2 b. Discriminant analysis function plots. a for the grouped Sistan-Belutschistan samples together with all other subspecies, $b$ for the ungrouped Sistan-Belutschistan samples together with the A. m. meda subgroups.

A cluster analysis based on of group means of znormalized character data also showed the SistanBelutschistan bees to be closely linked to the $A$. $m$. meda cluster (Fig. 3). Again they had closer affinity to the Iran SE group, and from the other subspecies they were next linked to $A$. $m$. syriaca, then to the A. m. anatoliaca / A. m. caucasica cluster, and then to $A$. m. carnica, to A. m. mellifera followed at some distance by $A$. m. jemenitica. Table 2 gives an excerpt from the distance matrix reflecting the Euclidian distances from Belutschistan bees, similarly showing the relative closeness to $A$. $m$. meda groups, to $A$. $m$. syriaca, followed by the other subspecies with $A$. $m$. jemenitica placed furthest away. 


\section{ARAŞTIRMA MAKALESI / RESEARCH ARTICLE}

\section{UPGMA dendrogramm, z-normalized data, euclidian distance}

Iran SE
Iran mass
Iran central
Irak
Iran NE
Belutschistan
A. $m$. syriaca
A. $m$. caucasica
A. $m$. anatoliaca
A. $m$. carnica
A. $m$. mellifera
A. $m$. jemenitica

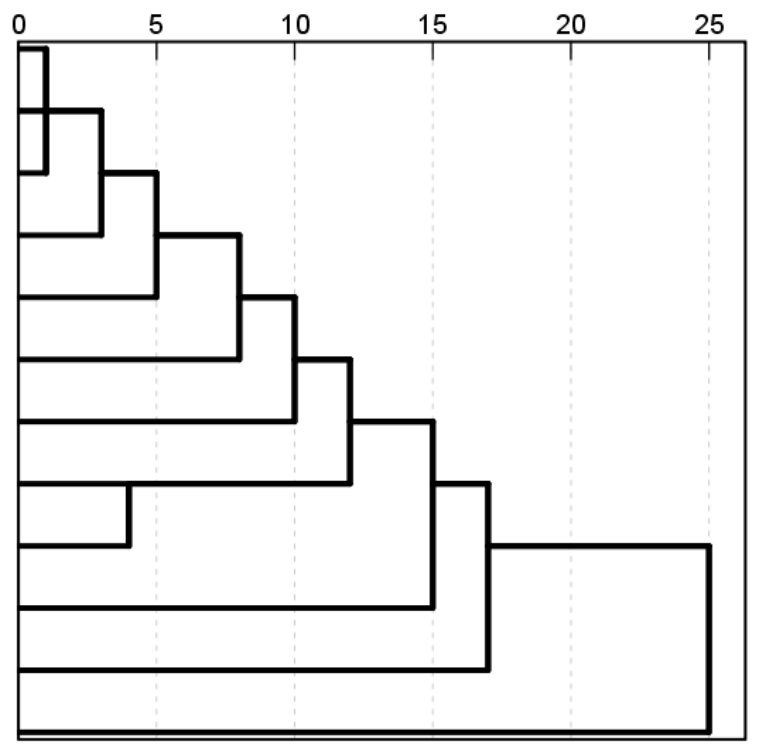

Fig. 3 Dendrogram showing the position of the Belutschistan bees in relation to other subspecies, and to subgroups of $A$. m. meda, based on z-normalized morphometric data

Table 2. Euclidian distance from the Belutschistan group based on z-normalized character data.

\section{Euclidian distance}

\begin{tabular}{|l|c|}
\hline \multicolumn{1}{|c|}{ Group } & Belutschistan \\
\hline A. m. mellifera & 10,487 \\
A. m. carnica & 9,465 \\
A. m. caucasica & 9,721 \\
A. m. anatoliaca & 7,628 \\
A. m. syriaca & 6,741 \\
A. m. jemenitica & 11,378 \\
Iran central & 5,436 \\
Iran NE & 6,550 \\
Iran SE & 5,558 \\
Iran mass & 6,091 \\
Irak & 5,516 \\
Belutschistan & 0,000 \\
\hline
\end{tabular}

\section{DISCUSSION}

In this study we investigate the honey bees $(A$. mellifera) at the south-eastern distribution boundary of Apis mellifera, in an area of specific interest due to its vicinity to the distribution area of the Eastern honey bee $A$. cerana. These sampling positions were approximately $300 \mathrm{~km}$ east of the currently most eastward sample of $A$. mellifera, at Delfarh $\left(28^{\circ} 58 \mathrm{~N} 57^{\circ} 38 \mathrm{E}\right)$ in the district of Kerman, which had been morphometrically analyzed by Ruttner et al. (1985). No bees had been suspected by these authors because of the extremely hot and dry desert climate generally adverse to beekeeping. This hot desert strip constitutes the separation line to the beginning of $A$. cerana territory in Pakistan, the width of which has thus been reduced by about one third until the next record of $A$. cerana at Thari (Pakistan, 34 ${ }^{\circ} 30^{\prime} \mathrm{N} 64^{\circ} 51^{\prime} \mathrm{E}$ ), but possibly the distance of separation might be even less. It might be not impossible but unlikely that there is any overlap between the species as the separating region is extremely unhabitable. The geographic situation is sketched out in Fig 1, based on Ruttner et al. (1985).

At the same time, the bees of Sistan-Belutschistan enrich the spectrum of $A$. m. meda by a subpopulation of clearly deviating properties. Apis mellifera meda, distributed throughout Iran, was first described by Skorikov in 1929 (Ruttner 1988), for a small location in its northern range. The first more detailed investigation by Ruttner et al. (1985) still remains the main reference in which, based on 


\section{ARAŞTIRMA MAKALESI /RESEARCH ARTICLE}

63 samples from Iran, they roughly outlined the approximate distribution limits. They further identified 5 discernible subpopulations in Iran (West and central Iran, Mazandaran, Northeast Iran and South-east Iran) but also extensions into Iraq and Southeast Anatolia. This work was later supplemented by Ftayeh et al. (1994), who clarified the distribution limit into northern Syria, and by Ruttner et al. (2000) showing altitude-related clinal variation pattern along the $36^{\circ} \mathrm{N}$ latitude up ad down the Elbrus Mountains to the Caspian sea. Later, Adl et al. (2007) confirmed the clear separation between west Iranian $A$. m. meda, east Anatolian A. m. anatoliaca and A. m. caucasica. Dolati et al. (2013) further differentiated Iranian $A$. $m$. meda into 9 subpopulation by geometric wing analysis. All these investigations were based on morphometry, but were recently supplemented by a few molecular studies, mostly restricted to partial areas (Kandemir et al. 2004, Rahini 2015). However, the complete amount of variation within A. m. meda and its geographical the pattern still needs to be sorted out, which is beyond the scope of this paper.

Discriminant analysis, as well as cluster analysis, clearly confirmed that Sistan-Belutschistan bees belong to $A$. m. meda, in spite of quite some deviations which in part may be interpreted as adaptations to the extremely dry-hot climate. Some particular features set them apart, which are small size (but bigger than $A$. $m$. jemenitica), light coloration particularly of tergite 4 which was lightercolored than in any of the other groups, and extremely short hairs. A distinctive trait is the relatively broad wings, and some extreme wing angles (A4, O26, b4, G18 and K19 which might be resulting from general wing shape. While distinctly different fro all other A. m. meda populations, Sistan-Belutschistan bees were closest related to the most adjacent South-Eastern A. m. meda population. Next to the $A$. meda population SistanBelutschistan bees were most similar to $A$. $m$. syriaca with resemblances in size and pigmentation. An mtDNA analysis including bees from Sistan-Beluschistan (Rahini, 2015) had showen their membership to the evolutionary $C$ line, thus supporting their status within the A. m. meda subspecies.

\section{Acknowledgement}

We thank Prof. N. Koeniger for discussions and for providing workspace, B. Springer for helping with the morphometric measurements. We thank the Islamic Azar University of Nowshahr and Chalus for financial support.

\section{REFERENCES}

Adl, M. B. F., Gencer, H. V. Firatli, C., Bahreini, R 2007. Morphometric characterization of Iranian (Apis mellifera meda), Centraj Anatolian (Apis mellifera anatoliaca) and Caucasian (Apis mellifera caucasica) honey bee populations. Journal of Apicultural Research and Bee World. 46: 225-231.

Dolati, L., Rafie, J. N., Khalesro, H. 2013.Landmark based morphometric study in the fore and hind wings of an Iranian race of Europaean Honeybee (Apis mellifera meda). Journal of Apicultural Science. 57: 187-197.

Rahini, A. 2015. Study of genetic diversity of Iranian honey bee (Apis mellifera meda Skorikow, 1829) populations using the mtDNA COI-COIl intergenic region. Biologija 61: 5459.

Ftayeh, A., Meixner, M., Fuchs, S. 1994. Morphometrical investigatio in Syrian honeybees. Apidologie 25: 396-401.

Kandemir, I., Kence, M., Kence, A. 2000. Genetic and morphometric variation in honeybee (Apis mellifera L.) populations of Turkey. Apidologie, 31: 343-356.

Meixner, M. D.1994. Analyse polymorpher Subspezies von Apis mellifera L.: Morphometrische und molekulare Untersuchungen an den europäischen Rassen Apis mellifera carnica und ligustica und den afrikanischen Rassen Apis mellifera monticola und scutellata. Ph.D. thesis, JohannWolfgang-GoetheUniversity, Frankfurt.

Ruttner, F. (1988) Biogeography and taxonomy of honeybees. Springer, Berlin

Ruttner, F., Pourasghar, D., Kauhausen, D. 1985. Die Honigbienen des Iran. Apidologie 16, 241264

Ruttner, F., Pour Elmi, M., Fuchs, S. 2000. Ecoclines in the Near East along the $26^{\circ} \mathrm{N}$ latitude in Apis mellifera L. Apidologie 31: 157165.

SPSS, 2015. SPSS for Windows, Release 23.0.0.0, standard version. IBM corporation, USA. 


\section{ARAŞTIRMA MAKALESI / RESEARCH ARTICLE}

\section{GENIŞLETILMIŞ ÖZET}

\section{Giriş}

$\mathrm{Bu}$ çalışmada özel bir ilgi alanına sahip olan coğrafyada Apis mellifera'nın güney-doğu dağılım sınırları yeniden araştırılmıştır. Daha öncesinde Sistan-Belutchistan bölgesinin çok fazla kuru çöl iklimine sahip olmasından dolayı balarısı Apis mellifera'nın bu bölgede olmadığı ancak $A$. florea'nın varlığı rapor edilmiştir. 2005 yııında yapılan bir arazi çalışmasında bu bölgede hem modern hem de geleneksel yöntemlerle bayağı bir arıcılık faaliyetleri yapıldığı bulunmuştur. Bu çalışmada bu bölge balarılarının detaylı morfometrik çalışması yapılmış ve diğer balarıları ile morfolojik iliş̧kileri araştırılmıştır.

\section{Materyal ve Metot}

Yazarlar biri olan Pour Elmi 2005 yılında bölgeyi güneyden kuzeye doğru ziyaret ziyaret etmiş ve 7 balarısı kolonisinden alkol içerisine örnekler toplamıştır. Bu örneklerden 3 tanesi Iranshahr $\left(27^{\circ} 10^{\circ} \mathrm{N}, 60^{\circ} 38^{\prime} \mathrm{E}\right.$, rakım $\left.660 \mathrm{~m}\right) .1$ tanesi Khash $\left(28^{\circ} 13^{\prime} \mathrm{N}, 61^{\circ} 11^{\prime} \mathrm{E}\right.$, rakım $14900 \mathrm{~m}$, ve diğer 3 tanesi ise Zahedan $\left(29^{\circ} 30^{\circ} \mathrm{N}, 60^{\circ} 50^{\prime} \mathrm{E}\right.$, rakım 1384 $\mathrm{m})$ şehrinden toplanmıştır (Şekil 1). Kovanlardan toplanan öçneklerden her kovandan 10 birey olacak şekilde Ruttner (1988)'de tanımlanan metoda göre 37 morfometrik karakter (16 vücut büyüklüğü, 7 renk, ve 11 kanat açısı) ölçülmüştür. Bu bölge arılarının morfometrik pozisyonunu belirlemek amacıyla 67 A. m. meda ve 128 diğer yakın balarısı alttürlerinin Oberursel veri tabanında bulunan kovan verileri ile karşılaştırılmıştır. Elde edilen veriler SPSS 23 kullanılarak diskriminat fonksiyon analizi ve UPGMA kümeleme analizleri ile çok değişkenli istatistiksel analizlere tabi tutulmuştur.

\section{Sonuç ve Tartışma}

Morfometrik karakterlerden bazılarının karşılaştırmalı sonuçları ve farklılıkları Tablo 1'de verilmiştir. Sistan-Beluchistan'dan elde edilen arıların diğer örneklere göre az sayıda olması nedeniyle bu bölge arılarının farklı lokasyonları gruplanamamıştır. Ancak tüm morfometrik ölçümlerde bu bölge arıları veri tabanında bulunan A. m. mellifera, A. m. carnica, A. m. caucasica ve A. $m$. anatoliaca'dan istatistiksel olarak anlamlı bir şekilde farklı bulunmuştur. $A$. m. syriaca'ya benzer büyüklükte fakat $A$. m. jemenitica'dan çok daha büyük bulunmuştur. Aynı zamanda diğer İran ve Irak bölgesindeki arılardan da çok az küçüktür. Kullanılan 37 karaktere göre diğer balarısı grupları ile benzerlik ve farklılıklara sahiptir. Bu karakterlerin tamamı kullanılarak yapılan çok değişkenli istatistiksel analizlerde Beluchistan bölgesinden toplanan arıların $A$. m. meda grubuna daha yakın çıktığı fakat $A$. m. syriaca ve $A$. m. anatoliaca'ya da benzerlik gösterdiği görülmüştür (Şekil 2). Morfometrik karakter ortalamalarının UPGMA kümeleme analizinde de $A$. m. meda kümesi ile bağlanmıştır. Diğer alttürlerden ise $A$. $m$. syriaca'ya ve daha sonra A. m. anatoliaca / A. m. caucasica grubuna daha sonra ise $A . m$. carnica, A. m. mellifera ve sonrasında ise uzaktan $A$. $m$. jemenitica'ya bağlanmaktadır (Şekil 3). Tablo 2'de Beluchistan balarılarının diğer balarısı alttürlerine olan öklid uzaklıkları gösterilmektedir. Bu uzaklıklar incelendiğinde UPGMA kümeleme analizindeki benzer ilişkiler görülmektedir. Bu bölge balarılarının yapılan detaylı çalışması ile Apis mellifera dağılımı diğer balarısı türü olan $A$. cerana'ya kadar yakınlaşmıştır. Hem diskriminant hem de Kümeleme analizi Beluchistan arılarının biraz farklılıklarla birlikte $A$. m. meda'ya bağlı olduğunu göstermiştir. Ayrıca yapılan mtDNA analizi (Rahini, 2015) ile bu bölge arılarının $C$ evrimsel koluna ait olduğu ve $A$. $m$. meda alttürünün de pozisyonunu belirlenmektedir. 